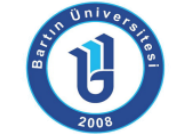

ISSN: 1308-7177
Bartin University

Journal of Faculty of Education

Volume 5, Issue 2, p. 312 - 327, June 2016

BARTIN - TURKEY

Doi: 10.14686/buefad.v5i2.5000189426

\title{
Dönüt Verme ve Düzeltme Türlerinin Altıncı Sınıf Öğrencilerinin Yazma Becelerine Etkisi
}

Nurettin YILDIZ, Yrd. Doç. Dr., Kahramanmaraş Sütçü İmam Üniversitesi, Eğitim Fakültesi, nyildiz@ksu.edu.tr

Öz: Bu araştırma, öğretme sürecinde öğrencilere dönüt ve düzeltme türlerinin yazma becerisine etkisini incelemek amacıyla yapılmıştır. Araştırma 2015-2016 öğretim yılı güz döneminde Kahramanmaraş ilinde bir ortaokulda 115 altıncı sınıf öğrencisi ile gerçekleştirilmiştir. Araştırmada karma yöntem kullanılmıştır. Nicel veriler Özkara (2007) tarafından Türkçeye uyarlanan "6+1 Analitik Yazma ve Değerlendirme Rubriği" kullanılarak SPSS 21.00 paket programına aktarılarak analiz edilmiştir. Araştırmanın nitel verileri ise içerik analizi yöntemiyle analiz edilmeye çalışılmıştır. Bu kapsamda ele alınan veriler Kuckartz'ın (2014) beş aşamalı içerik analizi yöntemi kullanılarak analiz edilmiştir. Araştırmanın amacına bağıı olarak üç grup oluşturulmuştur. Çalışmada A grubuna dönüt ve düzeltme, B grubuna sadece dönüt verme, $C$ grubuna ise puan belirtilme yapılmıştır. Araştırmada elde edilen bulgulara göre, yazma başarısının B-C gruplarına göre A grubu lehine anlamlı farklılık gösterdiği; $\mathrm{B}$ ve $\mathrm{C}$ grupları arasında da B grubu lehine anlamlı farklılık olduğu tespit edilmiştir. İçerik analizi sonucunda da $C$ grubuna göre A ve B grubu lehine; A ve B grupları arasında A grubu lehine anlamlı bir farklılık olduğu tespit edilmiştir.

Anahtar Kelimeler: dönüt verme, dönüt türleri, yazma becerisi, düzeltme, karma yöntem.

\section{The Effect of Giving Feedback and Correction Species on Sixth Grade Students' Writing Skills}

\begin{abstract}
This study was conducted to give feedback to the students in the learning process and writing skills in order to examine the effect of the correction. This research was conducted with 115 sixth grade students in a middle school in Kahramanmarass 2015-2016 academic year in the fall semester. Mixed methods were used in the research. Quantitative data Özkara (2007) adapted to Turkish "6 + 1 Analytical Writing and Assessment Rubrig" were analyzed transferring to SPSS 21.00 software package programme. The qualitative data of this research was tried to analyze with the content analysis method. The data discussed in this context was analyzed using the five stages of Kuckartz's (2014) content analysis method. Depending on the purpose of the study was formed three groups. In the study, feedback and correction to Group A, just feedback to Group B, scores indicated to Group C. According to the findings in the study showed significant differences in favor of the group $A$ as regards the B-C group; between the Group B and C were found to be significant differences. As a result of content analysis by the group $C$ in favor of group $A$ and $B$, it was found to have a significant difference in favor of group $A$ between the group A and B.
\end{abstract}

Key Words: feedback, feedback types, writing skills, correction, mixed method. 


\section{GíRiş}

Öğrencilere istendik davranış kazandırmak için öncelikle yapılması gereken eğitim hedeflerinin belirlenmesi, öğrenme ortamlarının hazırlanması ve öğrencilerden elde edilen ürünlerin değerlendirilmesidir (Bilen, 1996, s. 26). Kaliteli ve yüksek seviyede bir öğrenmenin gerçekleşebilmesi için öğrencinin öğrenip öğrenmediğini ya da hedeflenen öğrenmenin ne düzeyde gerçekleştiği ile ilgili olarak dönüt verme ve düzeltmenin yapılması gerekir. Bacanlı́ya (1999, s. 110) göre de öğrenci öğrendiği bilginin yeterli olup olmadığını güdülenme ortadan kalkmadan öğrenmelidir. Bu bağlamda dönüt verme ve düzeltme, öğretimin kalitesinin artmasında eğitim için önemli etkenlerden biridir. 2005 yılında eğitim programlarında gerçekleştirilen değişiklikle süreç değerlendirilmesine verilen önemin artması ile birlikte dönüt verme ve düzeltmenin öğretim içerisindeki yeri yadsınamayacak bir hâle gelmiştir (MEB, 2006).

Ingilizce "feedback" olarak ifade edilen dönüt verme, Türkçede Özçelik'in (1992) ifade ettiği gibi "dönüt, geribildirim, geri beslenme, sonuçların bilgisi" biçiminde ifade edilse de bu çalışmada dönüt verme ve düzeltme olarak kullanılmıştır. Dönüt verme ve düzeltme türlerinin yazma sonrasında birlikte kullanılması öğrencilerde ulaşımak istenen davranış değişikliğinin gerçekleşmesini sağlar. Dönüt verme, insan davranışlarının doğruluğu veya yanlışlığı hakkında bilgi veren (Peker, 1992, s. 35); düzeltme ise bireyin yaptığı bu yanlış davranışların nasıl düzeltileceğine ait yöntemleri gösteren bir süreçtir.

Eğitim sürecinde dönüt verme ve düzeltme genelde birlikte kullanılır (Demirel, 1999a, s. 135). Öğretmen ve öğrencilerin etkileşim içinde oldukları sınıf ortamlarında öğretmen ve öğrenci karşıııkı dönüt aldıklarında, dönüt vermenin yönlendirici, güdüleyici ve pekiştirici özelliklerinden dolayı öğretimin niteliğini olumlu yönde etkilemektedir (Dökmen, 1982; Sönmez, 1994; Tata, 2002). Öğrencinin bulunduğu öğrenim durumunda, güdülenme ortadan kalkmadan bilgilendirilmeye ihtiyacı vardır (Bacanlı, 1999). Bu bağlamda dönüt verme ve düzeltmenin zamanlamasını doğru ayarlamak gerekmektedir. Stres ve gerilim içindeyken yapılacak dönüt verme ve düzeltmeler büyük olasılıkla öğrencinin başarısız noktalarını ön plana çıkaracaktır (Tata, 2002, s. 482). Dönüt verme ve düzeltme etkinlikleri uygulamasında ulaşılmak istenen davranış değişikliği, hedef kitlenin bilgi ve beceri seviyesi ve diğer koşullar göz önünde bulundurulmalıdır. Sönmez'in (1994) de ifade ettiği gibi sınıf ortamlarında öğretmen tarafından sorulan sorulara, öğrencilerce verilen cevaplara öğretmenin verdiği "tamam, doğru, eksik, yanlış" gibi cevaplar birer dönüt vermedir.

\subsection{Dönüt Verme Türleri}

Ulaşılmak istenen hedefe göre farklı dönüt verme ve düzeltme türleri ortaya çıkmıştır. Akyıldız (1996), dönüt verme ve düzeltmenin davranışçı yaklaşıma göre içsel ve dışsal olmak üzere ikiye ayrıldığını ifade etmiştir. Dışsal dönüt verme ve düzeltme, sonuç bilgisi, doğru cevap bilgisi, açıklayıcı-ayrıntılı dönüt verme ve düzeltme, katkısal dönüt verme ve düzeltme olmak üzere dörde ayrılmıştır. Schimmel'e (1988) göre dönüt verme ve düzeltme dört grupta ifade edilebilir: Onaylayıcı (1), doğru cevap (2), açıklayıcı (3), bug-related (alışılmış hatalar) dönüt verme ve düzeltme (4). Onaylayıcı dönüt verme ve düzeltmede sadece öğrencinin cevabının doğru ya da yanlış olduğu belirtilir. Doğru cevap dönüt verme ve düzeltmede öğrencilere sadece doğru cevap verilir, öğrencilerden yanlış cevabı bulmaları istenir. Açıklayıcı dönüt verme ve düzeltmede öğrencinin verdiği yanlış cevap değerlendirilir, öğrenciye doğruya ulaşma yöntem ve teknikleri gösterilir. Bu dönüt verme ve düzeltmenin ikisinin de aktif şekilde uygulandığı bir yöntemdir. Bug-related dönüt verme ve düzeltmede ise öğrencinin bir konuyu öğrenirken yaptığı sistematik ve genellediği hataların düzeltilmesidir. Kara (1994), dönüt verme ve düzeltmeyi eğitim ortamlarına göre üçe; içerdiği bilgi miktarı ve bilginin veriliş biçimine göre ise dokuza ayırmıştır. Eğitim ortamına göre: a) Normal ve deneysel sınıf 
ortamında kullanılan, b) Bilgisayar destekli öğretim ortamında kullanılan, c) Programlı öğretim tekniğinde kullanılan dönüt verme ve düzeltmeler.

Dönüt verme ve düzeltme bilgi miktarı ve bilginin veriliş biçimine göre: Bilginin aralıklı veya sürekli verilmesi (1), notun aralıklı veya sürekli verilmesi(2), dağınık sözcüklerle dönüt verme ve düzeltmenin gerçekleşmesi (3), pekiştireçlerin verilmesi (4), doğru-yanlış dönüt verme ve düzeltmenin verilmesi (5), mevcut bilgi seviyesine göre dönüt verme ve düzeltmenin gerçekleşmesi (6), işbirliğine dayalı paylaşımlı dönüt verme ve düzeltmenin gerçekleşmesi (7), sınıfın tamamına uygulanan dönüt verme ve düzeltme (8), yazılı-sözlü dönüt verme ve düzeltmenin gerçekleşmesi (9). Baker \& Buckley'e (1996, s. 25) göre yanlış olan davranışlar zihinsel süreçten geçirildikten sonra öğrenci dönüt verme ve düzeltme bilgisine ihtiyaç duyacak, edindiği geri bildirim sayesinde öğrencinin performansı artacaktır. Baker \& Buckley (1996) dönüt verme ve düzeltmeye ait durumu Şekil 1'deki gibi ifade etmişlerdir.

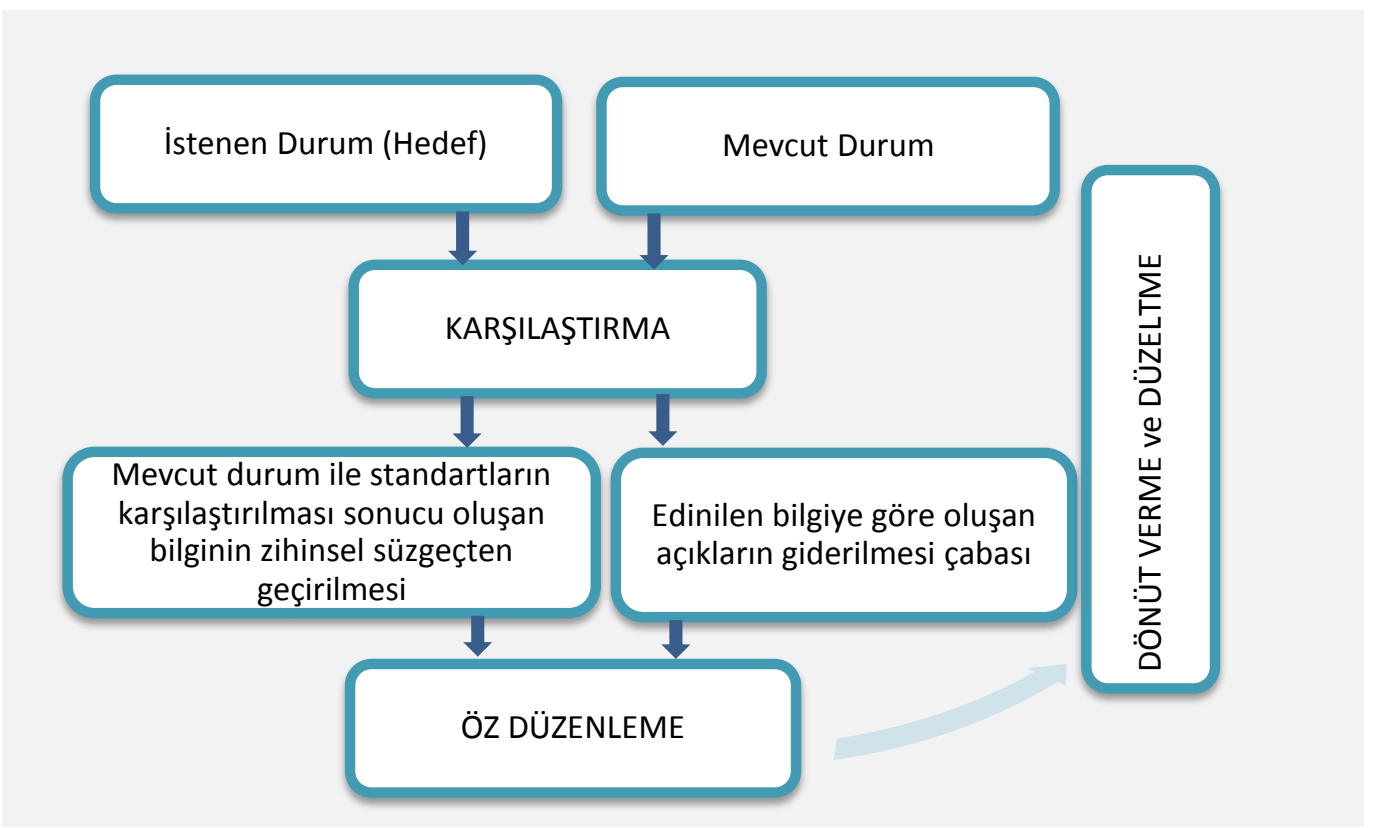

Şekil 1. Kontrol kuramı

Öğretmenlerin öğrencilerden ölçme ve değerlendirme sonucunda elde ettikleri durumları öğrencilere dönüt vererek düzeltmeleri onları bu konularda bilgilendirmeleri hem öğrenme hem de öğretme sürecinin iyileştirilmesinde çok önemli bir yere sahiptir (Alavi ve Kaivanpanah, 2007, s. 1). Dönüt verme ve düzeltmenin etkili olabilmesi için, öğrencilere uygulanan etkinlikler sonrasında, öğrencinin yeteneklerini vurgulayıcı ve istendik davranışları cesaretlendirici dönütler verilmelidir (Sönmez, 1994). Öğrencinin eğitim sistemi içerisinde davranış değişikliğini geliştirebilmesi için ölçme ve değerlendirme sürecinde dönüt verme ve düzeltme alması gerekir. Dönüt verme ve düzeltme sürekli tek taraflı gerçekleştiğinde ise öğrencilerde olumsuz bir alışkanlığa sebep olabilir. Bu açıdan öğretmenlerin öğrencileri de aktif hâlde öğretime dâhil etmeleri gerekmektedir. Bütün bu dönüt verme ve düzeltme türlerinden sonra, genelde eğitimde özelde ise Türkçe eğitiminde yazma becerisinde dönüt verme ve düzeltme türlerinden hangisinin kullanılması gereği önem arz etmektedir.

\subsection{Dönüt Verme ve Düzeltmenin Yazma Becerisine Etkisi}

Dört temel dil becerisi içerisinde öğrencilerin en son kazandıkları beceri yazma becerisidir. Yazma becerisi bilişsel, duyuşsal ve devinişsel olmak üzere üç boyutu da içerisinde barındırır. Kazanılan bilgilerin, duyumların ve okunanların belli bir düzen içerisinde zihinsel 
işlemlerden geçirilerek yorumlanması bilişsel boyut; ifadenin yalınlığı, akıcılığı, çekiciliği duyuşsal boyut; yazma araçlarının kullanılması ve kas hareketleri devinişsel boyuttur (Köksal, 2001, s. 17). Yazma, duyduklarımızın, düşündüklerimizin, tasarladıklarımızın (Sever, 2011, s. 21); belli kurallara uygun şekilde sembollerle anlatılmasıdır (Özbay, 2006, s. 115). Yazma, doğuştan gelen bir özellik olmaktan çok, çaba gerektiren, gerekli ve doğru eğitim alınarak kazanılabilen bir beceridir (Akbayır, 2010; Aktaş ve Gündüz, 2007; Kavcar, Oğuzkağan ve Aksoy, 2004). Yazılı bir ürün çeşitli aşamalardan geçtikten sonra elde edilebilir. Bu aşamalar, konunun seçimi, seçilen konun sınırlandırılması, konunun ana maddesinin belirlenmesi, konu hakkında söyleneceklerin bulunması, düşüncelerin bir plan dâhilinde yazılması, yazının değerlendirilmesi (Temizkan, 2003, s. 5) şeklinde söylenebilir. Yazan kişin bu aşamaları doğru uygulayıp uygulamadıkları kontrol altında değerlendirilmesi gerekmektedir. Bu aşamalar içinde yazının değerlendirilmesi tüm önceki aşamaların kontrolü anlamına geldiği için dönüt verme ve düzeltme yazma becerisinin gelişmesinde çok önemli bir yere sahiptir diyebiliriz.

Yazma becerisinin doğru şekilde gerçekleşebilmesi için öncelikle yazanın nitelikli bir bilgi birikimine sahip olması daha sonra da yazma etkinliği içerisinde bulunması gerekmektedir. Yazan yazdığı metnin niteliğini olduğunun değerlendiremeyeceği için burada yazılan metni değerlendirecek alan uzmanının işe dâhil olması gerekiyor. Yazma becerisinin geliştirilmesinde öğrenciler için öğretmen, yazarlar için hakemler uzman sayılacağından onların verecekleri dönüt verme ve düzeltmeler önemlidir. Mevcut düzey ile olması gereken düzey arasındaki boşluğun tamamlanması (Bekiroğlu, 2008) olarak tanımlanan dönüt verme ve düzeltmenin zamanında ve yerinde yapılması yazma becerisinde kazandırılmak istenen davranışın pekiştirilmesinde önemlidir. Dönüt verme ve düzeltmenin yazma becerisinde faydalı olabilmesi ve öğretenin rehberlik edebilmesi için Sadler'in (1989) belirtiği hususlara dikkat edilmesi gerekmektedir:

a) Öğrencilerin hangi bilgi ve becerilere sahip olması gerektiği,

b) Öğrencinin sahip olması gereken bilgi ve beceriye göre yaptığı çalışmaların karşılaştırılması,

c) Aradaki boşluğun kapatılması için öğrencinin neler yapabileceğinin önerilmesi.

Literatürde, öğrencilerin eğitim dönemleri değerlendirildiğinde diğer dil becerilerine göre yazma becerisinin istenilen seviyede olmadığı (Akbayır, 2010; Özbay, 2006; Sever, 2011; Ünalan, 2001) belirtilmiş ve bunun sebebi olarak öğrenci, öğretmen ve program temelli olarak açıklanmaya çalışılmıştır. Yazma eğitiminde süreç ve ürün odaklı iki yaklaşım mevcuttur. Öğrenciler yazma eğitimini gerçekleştirirken ürün odaklı yaklaşıma maruz kaldıklarından istenilen yazma becerisini sergileyememektedirler. Yazı yazarken öğrencilere dönüt ve düzeltmenin uygulanmaması yazma süreci içerisinde yer almaması yazma eğitimini olumsuz etkilemektedir (Karatay, 2013, s. 22). Bunun neticesinde de öğrenciler yazma becerisine karşı olumsuz tutum içerisine girmektedirler (Coşkun, 2005).

Öğretmen, öğrenme sürecini etkileyen faktörleri dikkatlice takip etmeli, gözlemlemeli, öğrencilerin yazma etkinliklerinde yaşadıkları eksiklik ve güçlüklerinden anında haberdar olmalı ve bu aksaklıkların zamanında, doğru bir şekilde düzeltilmesini sağlayacak önlemler alıp uygulamalıdır. Yazma eğitiminin temel unsuru öğrencidir. Yazma becerisinin geliştirilmesinde temel unsur olan öğrenciye verilecek dönüt ve düzeltmeler yazma niteliğinin artmasında önemli katkı sağlayabilir.

\subsection{Araştırmanın Amacı}

Diğer dil becerileri gibi yazma becerisi de öğrenilenlerin uygulanması ile kazanılabilir. Yazma becerisi diğer becerilere oranla daha fazla beceriyi düşünme, yönlendirilen ifadeleri kullanma, sınıflama, değerlendirme, özetleme gibi anlamayı ve zihinsel becerileri de (Güneş, 2007, s. 159) içerisinde barındıran bir dil becerisidir. Bu bağlamda öğrencilerin yazma becerisini 
doğru ve güzel bir şekilde tek başlarına yapmaları çok zor olabilir. Bu aşamada öğretmenlerin öğrencilere yazma becerisini kazanmada ve kullanmada rehber olmaları gerekmektedir. Öğretmenlerin yapacakları dönüt verme ve düzeltmenin yazma becerisini olumlu yönde geliştirebileceği düşünülen bu çalışmada dönüt verme ve düzeltme türlerinin yazma becerisine olan etkisinin ne düzeyde olduğu sınanmıştır. Bu amaç doğrultusunda şu sorulara cevap aranmaya çalışılmıştır:

1. Dönüt verme ve düzeltme türlerinin altıncı sınıf öğrencilerinin yazma becerisine etkisi hangi düzeydedir?

2. Dönüt verme ve düzeltme türlerinin altıncı sınıf öğrencilerinin 6+1 Analitik Yazma ve Değerlendirme Rubriği boyutlarına göre durumu nasıldır?

\section{YÖNTEM}

\subsection{Araştırmanın Modeli}

$\mathrm{Bu}$ araştırma, açıklayıcı desende karma yöntemle modellenmiştir. Karma modelde öncelikle nicel veriler toplanıp analiz edilir daha sonra bu verileri detaylandırmak için nitel yöntem kullanılır (Creswell, 2009, s. 14). Çalışmanın nicel boyutu deneme modellerinden kontrol gruplu ön- son test modelindedir. Bu tür modellemede hem deney öncesi hem deney sonrası ölçmeler gerçekleştirilerek deney öncesi ve sonrası bağımsız değişkenin deney grubuna olan etkisi tespit edilmeye çalışılır (Kıncal, 2010). Çalışmanın nitel boyutunda içerik analizi yöntemi kullanılmıştır. Bu yöntemde, ilk algılardan farklı olarak kapalı içeriğin anlaşılmasını sağlamak amacıyla yapılan ikinci bir okuma eylemidir (Bilgin, 2006).

\section{2. Çalışma Grubu}

Araştırmanın çalışma grubunu 2015-2016 eğitim öğretim yılında Kahramanmaraş il merkezinde eğitim-öğretim gören 6 . sınıf öğrencileri oluşturmaktadır. Araştırma A grubu 38, B grubu 40, C grubu ise 37 olmak üzere toplam 115 öğrenci üzerinde yürütülmüştür. Çalışma grubu seçkisiz olmayan amaçsal örnekleme türlerinden tabakalı amaçsal örnekleme/kota yöntemi tercih edilmiştir. Bu yöntem, hedeflenen alt grupların özelliklerini ortaya çıkarmak, betimlemek ve bunlar arasındaki ilişkiye imkan tanımak için kullanılır (Büyüköztürk, vd., 2011, s. 90). Gruplar oluşturulurken 2014-2015 eğitim öğretim yılı Türkçe dersi akademik başarı ortalamaları; yazma ön rubrik puanları; cinsiyet ve aynı Türkçe öğretmeninin derse girmesi göz önünde bulundurulmuştur. Gruplar arası dağılımın homojenliğinin tespiti için iki yönlü varyans analizi (Anova) kullanılmıştır.

Tablo 1

Grupların Türkçe Dersi Başarı Durumu

\begin{tabular}{|c|c|c|c|c|c|c|}
\hline Grup & $\mathrm{N}$ & Min. & Max. & Ortalama & $\mathrm{F}$ & $P$ \\
\hline A Grubu & 38 & 2 & 5 & 4.11 & \multirow{3}{*}{2.198} & \multirow{3}{*}{.116} \\
\hline B Grubu & 40 & 3 & 5 & 4.33 & & \\
\hline C Grubu & 37 & 2 & 5 & 4.00 & & \\
\hline
\end{tabular}

Çalışmaya katılan grupların 2014-2015 eğitim-öğretim yılı Türkçe ders notları değerlendirildiğinde anlamlı farklılık olmadığı ( $p>.05)$ tespit edilmiştir. Bu sonuçla grupların arasında istatistiksel olarak anlamlı farklılığın olmadığı söylenebilir. 


\subsection{Araştırmanın Uygulama Süreci}

Araştırmanın amacına uygun olarak üç grup oluşturulmuş ve grupların denkliğine bakmak için gruplara ön rubrik yapılmıştır. Gruplara 4 hafta dönüt verme ve düzeltme türleri uygulanmış daha sonra son rubrik gerçekleştirilmiştir. Uygulama sürecinin aşamaları Tablo 4'te verilmiştir.

Tablo 2

Gruplara Uygulanan Uygulama Süreci

\begin{tabular}{|c|c|c|c|}
\hline Gruplar & Ön Rubrik & Uygulama & Son Rubrik \\
\hline A Grubu & \multirow{3}{*}{$\begin{array}{c}\text { 6+1 Analitik Yazma ve } \\
\text { Değerlendirme } \\
\text { Rubriği }\end{array}$} & $\begin{array}{l}\text { Yanlışları gösterme ve düzeltme } \\
\text { verme. }\end{array}$ & \multirow{3}{*}{$\begin{array}{c}\text { 6+1 Analitik Yazma ve } \\
\text { Değerlendirme } \\
\text { Rubriği }\end{array}$} \\
\hline B Grubu & & Yanlışları gösterme dönütü verme. & \\
\hline C Grubu & & Sadece aldıkları puan dönütü verme. & \\
\hline
\end{tabular}

\subsection{Veri Toplama Aracı}

2.4.1. Veri Toplama Aracının Nicel Boyutu: Çalışma deneme modellerinden kontrol gruplu ön rubrik-son rubrik modelindedir. Dönüt verme ve düzeltmelerden tüm gruplara $6+1$ Analitik Yazma ve Değerlendirme Rubriği'ne uygun seçilen metinler yazılması istenmiş ve yazılan metinler puanlanmıştır. Grupların yazma başarılarını değerlendirmek için 6 . sınıf Türkçe kitabında yer alan 3. tema olan "sevgi" ve 5. tema olan "milli kültür" temalarındaki metinler yazma becerilerine uygun şekilde düzenlenmiştir. Seçilen bu metinleri değerlendirmek için 6+1 analitik yazma değerlendirme rubriği kullanılarak 1 ile 5 puan arasında bir skala oluşturulmuştur. 6+1 Analitik Yazma ve Değerlendirme Rubriği, ABD Kuzeybatı Bölgesel Eğitim Laboratuvarı'nda geliştirilmiştir. Bu rubrik Özkara (2007) tarafından Türkçeye uyarlanmıştır. $6+1$ analitik yazma değerlendirme rubriği organizasyon, fikirler, üslup, kelime seçimi, cümle akıcılığı, imla ve sunum olmak üzere yedi boyuttan meydana gelmiştir. Seçilen metinler $6+1$ analitik yazma değerlendirme rubriğine göre değerlendirilmiştir.

Üç Türkçe öğretmeni tarafından her bir boyut için değerlendirme yapılmıştır. Her bir boyuta verilen en yüksek puan 5; en düşük puan 1 olarak değerlendirilmiştir. Çalışmanın ön rubriğinde, gruplara seçilen metinler yazdırılmış ve rubriğe ait puanlama ile değerlendirme yapılmıştır. Daha sonra bağımlı değişken olarak A grubuna ön rubrikteki hataları geri dönüt olarak gösterilmiş ve gerekli düzeltmelerin nasıl yapılacağı araştırmacı tarafından gösterilmiştir. $B$ grubuna ön rubrikteki hataları geri dönüt olarak iletilmiş fakat yanlışların doğru biçimleri gösterilmemiş; C grubuna ise sadece ön rubrik puanları ve hata sayıları bildirilmiştir. Üç gruba uygulanan metinler uzmanla tarafından değerlendirilmiştir.

2.4.2. Veri Toplama Aracının Nitel Boyutu: Çalışmanın nitel verileri içerik analizi yöntemiyle analiz edilmeye çalışılmıştır. Her gruptan 3'er tane ön yazma ve 3'er tane son yazma örnekleri toplamda 18 veri Kuckartz'ın (2014) beş aşamalı içerik analizi yöntemi ile analiz edilmeye çalışılmıştır. Bu kapsamda önce metinler okunur ve genel bir değerlendirmeye varılır; daha sonra kategoriler oluşturulur; üçüncü basamakta her bir kategori için kodlamalar yapılarak alt kategoriler elde edilir; dördüncü aşamada elde edilen verilerin analizi yapılır ve sonuçlar ortaya konur. Gruplara ait 9 ön rubrig ve 9 son rubrig 3 Türkçe öğretmeni tarafından değerlendirilmiş ve araştırmacı tarafından $6+1$ analitik yazma değerlendirme rubriğine göre kodlanmıştır.

\section{BULGULAR}

Çalışmanın bu bölümünde elde edilen nicel ve nitel bulgulara yer verilmiştir. Elde edilen bulgular araştırmanın alt problemlerine uygun olarak verilmiştir. 
"Dönüt verme ve düzeltme türlerinin altıncı sınıf öğrencilerinin yazma becerilerine etkisi hangi düzeydedir?" biçiminde oluşturulan hipotez için araştırmaya katılan öğrencilerin ön rubrik ile son rubrik arasında anlamlı bir farklılık olup olmadığını tespit etmek için t-testi yapılmıştır. Gruplara uygulanan ön-son rubrik analizi Tablo 3'te verilmiştir.

Tablo 3

Dönüt Verme ve Düzeltmenin Ön Rubrik-Son Rubrik Sonuçları

\begin{tabular}{llllll}
\hline $\begin{array}{l}\text { Varyansın } \\
\text { Kaynağı }\end{array}$ & Kareler toplamı & Sd & $\begin{array}{l}\text { Kareler } \\
\text { ortalaması }\end{array}$ & F & P \\
\hline Gruplar arası & 26962.88 & 2 & 13481.44 & 257.90 & .000 \\
\hline Grup içi & 5854.56 & 112 & 52.27 & & \\
\hline Toplam & 32817.44 & 114 & & & \\
\hline
\end{tabular}

Araştırmaya katılan grupların ön rubrik ortalamasının $\mathrm{O}=50.93, \mathrm{SS}=8.95$; son rubrik ortalamasının $\mathrm{O}=68.06, \mathrm{SS}=16.97$ olduğu ve gruplar arası $(p<.05)$ anlamlı bir fark olduğu Tablo 3'te tespit edilmiştir.

Dönüt verme ve düzeltme türlerinin uygulandığı gruplara göre son rubrikte anlamlı farklılığın belirlenmesi için tek yönlü varyans (ANOVA) analizi yapıımıştır.

Tablo 4

Dönüt Verme ve Düzeltmenin Son Rubrik Sonuçları

\begin{tabular}{llllll}
\hline $\begin{array}{l}\text { Varyansın } \\
\text { Kaynağı }\end{array}$ & Kareler toplamı & Sd & $\begin{array}{l}\text { Kareler } \\
\text { ortalaması }\end{array}$ & F & P \\
\hline Gruplar arası & 26962.88 & 2 & 13481.44 & 257.90 & .000 \\
\hline Grup içi & 5854.56 & 112 & 52.27 & & \\
\hline Toplam & 32817.44 & 114 & & & \\
\hline
\end{tabular}

Tablo 4 incelendiğinde ANOVA analiz rubriği tablosuna göre anlamlılık değeri $p<.05$ ten küçük olduğu görülmektedir. Dolayısıyla grupların son rubrikten aldıkları puanlar arasında anlamlı bir farklıığın olduğu söylenebilir. Bu anlamlı farklılığın nasıl olduğu Tablo 5'te verilmiştir.

Tablo 5

Dönüt Verme Düzeltmenin Gruplar Arasındaki Farkı

\begin{tabular}{lccccc}
\hline Gruplar & $\mathrm{N}$ & Ortalama & $\mathrm{SS}$ & $\mathrm{p}$ & Anlamlı Fark \\
\hline A & 38 & 88.45 & 5.87 & .000 & A-B,C \\
\hline B & 40 & 64.40 & 7.62 & .000 & B-C \\
\hline C & 37 & 51.11 & 8.02 & .000 & \\
\hline Toplam & 115 & & & & \\
\hline
\end{tabular}

A: Yazma beceresinde dönüt verme ve düzeltmenin uygulandığı grup.

B: Yazma beceresinde dönüt vermenin uygulandığı grup.

C: Yazma beceresinde dönüt verme ve düzeltmenin uygulanmadığı grup.

Tablo 5 incelendiğinde $A$ grubunun diğer gruplara göre; B grubun da $C$ grubuna göre son rubrikte anlamlı farklılık gösterdiği tespit edilmiştir.

Araştırmanın ikinci alt problemi olan "dönüt verme ve düzeltme türlerinin altıncı sınıf öğrencilerinin yazma becerilerindeki boyutlara göre durumu nasıldır?" sorusuna ait bulgular 7 ayrı boyuta göre verilmiştir. $6+1$ analitik yazma rubriğinin fikirler boyutuna ait bulgular Tablo 6 'da verilmiştir.

Tablo 6

6+1 Analitik Yazma Rubriğinin Fikirler Boyutu Analizi

\begin{tabular}{lll}
\hline Fikirler Boyutu & \multicolumn{1}{c}{ Ön Rubrik } & \multicolumn{1}{c}{ Son Rubrik } \\
\hline Fikirler anlaşılır bir şekilde yazılmış & AGÖ1 & AGS1, AGS2; BGS2, BGS3; CGS2 \\
Savunduğu fikirleri destekleyebilmiş & BGÖ2 & AGS1, AGS3; BGS2; CGS1 \\
Bilgi ve deneyimlerinden yararlanmış & AGÖ2, CGÖ3 & AGS2, AGS3; BGS2, BGS3 \\
\hline
\end{tabular}




\begin{tabular}{lll}
\hline $\begin{array}{l}\text { Konun ana fikri verilmiş } \\
\text { Gereksiz detaydan kaçınılmış, önemli olan } \\
\text { belirtilmiş }\end{array}$ & $\begin{array}{l}\text { BGÖ2 } \\
\text { CGÖ1 }\end{array}$ & $\begin{array}{l}\text { AGS1,AGS2, AGS3; BGS2 } \\
\text { AGS2, AGS3; BGS2, BGS3; CGS1 }\end{array}$ \\
\hline $\begin{array}{l}\text { AGÖ1 : A grubu ön rubrik birinci kişi } \\
\text { AGÖ2 : A grubu ön rubrik ikinci kişi }\end{array}$ & $\begin{array}{c}\text { BGÖ1 : B grubu ön rubrik birinci kişi } \\
\text { BGÖ2 : B grubu ön rubrik ikinci kişi }\end{array}$ & $\begin{array}{l}\text { CGÖ1 : C grubu ön rubrik birinci kişi } \\
\text { CGÖ2 : C grubu ön rubrik ikinci kişi }\end{array}$ \\
AGÖ3 : A grubu ön rubrik üçüncü kişi & BGÖ3 : B grubu ön rubrik üçüncü kişii & CGÖ3 : C grubu ön rubrik üçüncü kişi \\
AGS2 : A grubu son rubrik birinci kişi rubrik ikinci kişi & BGS1 : B grubu son rubrik birinci kişi & CGS1 : C grubu son rubrik birinci kişi \\
AGS3 : A grubu son rubrik üçüncü kişi & BGS3 : B grubu son rubrik ikinci kişi rubrik üçüncü kişi & CGS2: C grubu son rubrik ikinci kişi \\
CGS3 : C grubu son rubrik üçüncü kişi
\end{tabular}

Fikirler boyutuna ilişkin Tablo 6 incelendiğinde, dönüt verme ve düzeltme türlerine ait uygulamaların grupları farklı düzeyde etkilediğini söylemek mümkündür. Bu bağlamda fikirler boyutunun alt kategorileri incelendiğinde son rubrik lehine nicel bir üstünlüğün olduğu görülmektedir. Ön rubrikte dönüt verme ve düzeltme türlerinin fikirler boyutunun alt kategorileri olan fikirlerin anlaşıı bir şekilde yazııması AGÖ1 kişisi; savunduğu fikirleri destekler şekilde ifade edebilmesi $\mathrm{BGO2}$ kişisi; bilgi ve deneyimlerinden yararlanmış BGO2, CGS3 kişileri; konunun ana fikrinin verilmesi $\mathrm{BGO2}$ kişisi; gereksiz detaydan kaçınılmış, önemli olan belirtilmiş kategorisinde AGÖ1 kişisi tarafından ön rubrikte yeterli düzeyde olsa da diğer öğrencilerin yetersiz olduğu tespit edilmiştir.

Son rubrikte dönüt verme ve düzeltme türlerinin farklı şekilde uygulandığı gruplarda farklı şekilde değişme göstermiştir. Dönüt verme ve düzeltme türlerin uygulandığı fikirler boyutunun alt kategorileri olan;

Fikirlerin anlaşılır bir şekilde yazılması AGS1, AGS2; BGS2, BGS3; CGS2 kişileri;

Savunduğu fikirleri destekler şekilde ifade edebilmesi AGS1, AGS3; BGS2; CGS1 kişileri;

Bilgi ve deneyimlerinden yararlanmış AGS2, AGS3; BGS2, BGS3 kişileri;

Konunun ana fikrinin verilmesi AGS1,AGS2, AGS3; BGS2 kişileri; gereksiz detaydan kaçınılmış, önemli olan belirtilmiş kategorisinde AGS2, AGS3; BGS2, BGS3; CGS1 kişileri tarafından son rubrikte doğru cevap vermişlerdir.

Bu sonuçla dönüt verme ve düzeltme türlerinin uygulama sürecinde $\mathrm{A}$ grubundan alınan 3 katıımcıdan yanlışların gösterilmesi ve doğru cevapların verilmesi biçiminde uygulanan dönüt verme ve düzeltme türleri son rubrik lehine anlamlı bir artış gösterirken, B grubuna uygulanan sadece yanlışların gösterilmesi dönüt verme $C$ grubuna göre anlamlı bir artış göstermiş; $C$ grubunda sadece puan dönütü uygulanmış ve bu dönüt neticesinde anlamlı bir fark oluşmamıştır. Bu sonuçla yazma eğitiminde fikirler boyutunda dönüt verme ve düzeltme türleri birlikte kullanılmalıdır denilebilir.

$6+1$ analitik yazma rubriğinin organizasyon boyutuna ait bulgular Tablo 7'de verilmiştir. Tablo 7

6+1 Analitik Yazma Rubriğinin Organizasyon Boyutu Analizi

\begin{tabular}{|c|c|c|}
\hline Organizasyon Boyutu & Ön Rubrik & Son Rubrik \\
\hline Dikkat çekici bir girişle başlanılmış & CGÖ1 & AGS2; BGS2; CGS1 \\
\hline Fikirler birbirine özenle bağlanmış & BGÖ2 & AGS1, BGS2 \\
\hline $\begin{array}{l}\text { Sıralama bir mantık içinde yapılmış } \\
\text { ve detaylara özen gösterilmiş. }\end{array}$ & & AGS2, AGS3 \\
\hline Başlık ana fikri yansıtabilmiş & CGÖ1 & AGS1,AGS2, AGS3; BGS2 \\
\hline $\begin{array}{l}\text { Metnin yapısı akıcı ve yaş seviyesine } \\
\text { uygun düzenlenmiş. }\end{array}$ & BGÖ3 & AGS2, AGS3; CGS1 \\
\hline
\end{tabular}

Organizasyon boyutuna ilişkin Tablo 7 incelendiğinde, dönüt verme ve düzeltme türlerine ait uygulamaların grupları farklı düzeyde etkilediğini söylemek mümkündür. Bu bağlamda organizasyon boyutunun alt kategorileri incelendiğinde son rubrik lehine nicel bir farklılık görülmektedir. Ancak bu nicel farklılık sadece A grubu lehinedir. Diğer iki grup arasında nicel bir farklılık yoktur. 
Ön rubrikte dönüt verme ve düzeltme türlerinin organizasyon boyutunun alt kategorileri olan;

Dikkat çekici bir girişle başlanıımasını CGÖ1 kişisi;

Fikirlerin birbirine özenle bağlanmasını BGÖ2 kişisi;

Sıralamanın bir mantık içinde yapılması ve detaylara özen gösterilmesine ait yazma becerisini hiçbir katılımcı gerçekleştirememiş;

Başlığın ana fikri yansıtabilmesini CGÖ1 kişisi;

Metnin yapısı akıcı ve yaş seviyesine uygun düzenlenmesini BGÖ3 kişisi tarafından ön rubrikte yeterli düzeyde olsa da verileri incelenen diğer öğrencilerin yetersiz olduğu tespit edilmiştir.

Organizasyon boyutuna ait son rubrikte dönüt verme ve düzeltme türlerinin grupları farklı şekilde etkilediği tespit edilmiştir. Dönüt verme ve düzeltme türlerin uygulandığı organizasyon boyutunun alt kategorileri olan;

Dikkat çekici bir girişle başlanılmasını AGS2; BGS2; CGS1 kişileri;

Fikirler birbirine özenle bağlanmasını AGS1, BGS2 kişileri;

Sıralamanın bir mantık içinde yapılması ve detaylara özen gösterilmesine AGS2, AGS3 kişileri;

Başlığın ana fikri yansıtabilmesini AGS1,AGS2, AGS3; BGS2 kişileri;

Metnin yapısı akıcı ve yaş seviyesine uygun düzenlenmesini AGS2, AGS3; CGS1 kişileri son rubrikte doğru cevap vermişlerdir.

Bu sonuçla dönüt verme ve düzeltme türlerinin uygulama sürecinde $A$ grubuna yanlışların gösterilmesi ve doğru cevapların verilmesi biçiminde uygulanan dönüt verme ve düzeltme son rubrik lehine farklılık gösterirken, B grubuna uygulanan dönüt verme anlamlı bir farklılık göstermemiş; C grubunda sadece puan dönütü uygulanmış ve bu dönüt neticesinde anlamlı bir fark oluşmamıştır. Bu sonuçla yazma eğitiminde organizasyon boyutunda dönüt verme ve düzeltme birlikte kullanılmalıdır diyebiliriz. Bu boyutun öğretimi bir süreç içerisinde olduğu için dönüt verme ve düzeltmenin uzun süre uygulanması gerekmektedir denilebilir.

Tablo 8

6+1 analitik yazma rubriğinin üslup boyutuna ait bulgular Tablo 8'de verilmiştir.

6+1 Analitik Yazma Rubriğinin Üslup Boyutu Analizi

\begin{tabular}{lcl}
\hline Üslup Boyutu & Ön Rubrik & \multicolumn{1}{c}{ Son Rubrik } \\
\hline Seçilen kelimelerle doğal ve etkili bir dil oluşturulmuş & CGÖ1 & AGS1, AGS3; CGS2 \\
Fikirler yazının amacına uygun düzenlenmiş & BGÖ2 & AGS2, BGS3 \\
Açıklayıcı ve ikna edici üslup kullanılmış & & AGS1 \\
Anlatımı kişisel ve etkili kılma & & BGS2; CGS1 \\
\hline
\end{tabular}

6+1 analitik yazma rubriğinin üslup boyutuna ilişkin Tablo 8 incelendiğinde, dönüt verme ve düzeltme türlerine ait uygulamaların grupları farklı düzeyde etkilediğini söylemek mümkündür. Bu bağlamda üslup boyutunun alt kategorileri incelendiğinde son rubrik lehine nicel bir farklılık görülmemiştir. Bu sonuçla üslup boyutunda dönüt verme ve düzeltmenin yazma becerilerinin geliştirilmesinde diğer boyutlara göre yetersiz olduğu söylenebilir.

6+1 analitik yazma rubriğinin kelime seçimi boyutuna ait bulgular Tablo 9'da verilmiştir. Tablo 9

6+1 Analitik Yazma Rubriğinin Kelime Seçimi Boyutu Analizi

\begin{tabular}{lll}
\hline Kelime Seçim Boyutu & Ön Rubrik & \multicolumn{1}{c}{ Son Rubrik } \\
\hline Seçilen kelimelerin özgün ve uygunluğu & AGÖ2; CGÖ1 & AGS1, AGS2; CGS1 \\
$\begin{array}{l}\text { Dil ve ifade şeklinin doğallı̆ı } \\
\text { Sıfatlar, zarflar ve fiiller yerli yerinde kullanılmış }\end{array}$ & BGÖ2, BGÖ3 & AGS1, AGS2; BGS2, BGS3 \\
$\begin{array}{l}\text { Deyim ve atasözlerinden yararlanılmış } \\
\text { Kelime çeşitliliği yönünden zengin }\end{array}$ & AGÖ2, BGÖ3 & AGS1, AGS2, AGS3; BGS2; CGS1 \\
ve tamlamalara yer verilmiş. & & AGS1, BGS1 \\
\hline
\end{tabular}


Kelime seçimi boyutuna ilişkin Tablo 9 incelendiğinde, dönüt verme ve düzeltme türlerine ait uygulamaların grupları farklı düzeyde etkilediğini söylemek mümkündür. Bu bağlamda kelime seçimi boyutunun alt kategorileri incelendiğinde son rubrik lehine nicel bir farklılık olduğu görülmektedir. Ön rubrikte dönüt verme ve düzeltme türlerinin kelime seçimi boyutunun alt kategorileri olan;

Seçilen kelimelerin özgün ve uygun olması AGÖ2, CGÖ1 kişileri;

Dil ve ifade şeklinin doğal olmasını BGÖ2, BGÖ3 kişileri;

Sıfatlar, zarflar ve fiiller yerli yerinde kullanılması CGÖ1 kişisi;

Kelime çeşitliliği yönünden zengin ve tamlamalara yer verilmesine ait yazma becerisini hiçbir katıımcı gerçekleştirememiş;

Deyim ve atasözlerinden yararlanılması AGÖ2, BGÖ3 kişileri ön rubrikte yeterli düzeyde olsa da diğer öğrencilerin yetersiz olduğu tespit edilmiştir.

Kelime seçimi boyutuna ait son rubrikte dönüt verme ve düzeltme türlerinin grupları farklı şekilde etkilediği tespit edilmiştir. Dönüt verme ve düzeltme türlerin uygulandığı kelime seçimi boyutunun alt kategorileri olan;

Seçilen kelimelerin özgün ve uygun olması AGS1, AGS2, CGS1 kişileri;

Dil ve ifade şeklinin doğal olmasını AGS1, AGS2, BGS2, BGS3 kişileri;

Sıfatlar, zarflar ve fiiller yerli yerinde kullanılması AGS1, AGS2, AGS3, BGS2, CGS1 kişileri;

Deyim ve atasözlerinden yararlanılması AGS1, AGS2, AGS2, BGS3 kişileri;

Kelime çeşitliliği yönünden zengin ve tamlamalara yer verilmesine AGS1, BGS1 kişileri tarafından son rubrikte verdikleri doğru cevaplar artmaktadır.

Dönüt verme ve düzeltme türleri $\mathrm{A}$ grubundan alınan 3 katılımcıdan yanlışların gösterilmesi ve doğru cevapların verilmesi biçiminde uygulanan dönüt verme ve düzeltme son rubrik lehine anlamlı bir artış gösterirken, $\mathrm{B}$ grubuna uygulanan sadece yanlışların gösterilmesi dönüt verme türü $C$ grubuna göre anlamlı bir artış göstermiş; $C$ grubunda sadece aldıkları puan dönütü uygulanmış ve bu dönüt neticesinde anlamlı bir fark oluşmamıştır. Bu sonuçla yazma eğitiminde kelime seçimi boyutuna ait yazma becerilerinin geliştirilmesinde dönüt verme ve düzeltme türlerinin birlikte kullanılması olumlu farklılık oluşturduğu söylenebilir.

6+1 analitik yazma rubriğinin cümle akıcılığı boyutuna ait bulgular Tablo 10 'da verilmiştir.

Tablo 10

6+1 Analitik Yazma Rubriğinin Cümle Akıcılığı Boyutu Analizi

\begin{tabular}{lll}
\hline Cümle Akıcılı̆ı Boyutu & Ön Rubrik & Son Rubrik \\
\hline Cümlelerin oluşturulmasına özen gösterilmiş & CGÖ1 & AGS1, AGS2; BGS2 \\
Cümleler verilmek istenen fikri yansıtmış & AGÖ2, BGÖ2 & AGS1; CGS1 \\
$\begin{array}{l}\text { Cümleler uzunluk ve yapı olarak çeşitlilik arz etmekte } \\
\text { Cümlelerin birbiriyle olan bağı iyi sağlanmış, }\end{array}$ & CGÖ1 & AGS1, AGS2; BGS2 \\
bağlaçlar doğru kullanılmış & AGÖ2 & AGS2, AGS3 \\
\hline
\end{tabular}

6+1 analitik yazma rubriğinin cümle akıcılığı boyutuna ilişkin Tablo 10 incelendiğinde, dönüt verme ve düzeltme türlerine ait uygulamaların grupları farklı düzeyde etkilediğini söylemek mümkündür. Bu bağlamda cümle akıcılığı boyutunun alt kategorileri incelendiğinde son rubrik lehine nicel bir farklılık olduğu görülmektedir. Ön rubrikte dönüt verme ve düzeltme türlerinin cümle akıcılı̆̆ boyutunun alt kategorileri olan;

Cümlelerin oluşturulmasına özen gösterilmesini CGÖ1 kişisi;

Cümlelerin verilmek istenen fikri yansıtmasını AGÖ2, BGÖ2 kişileri;

Cümlelerin uzunluk ve yapı olarak çeşitlilik arz etmesini CGÖ1 kişisi; 
Cümlelerin birbiriyle olan bağı iyi sağlanması, bağlaçların doğru kullanılmasını AGÖ2 kişisi ön rubrikte yeterli düzeyde gerçekleştirmiş olsalar da diğer öğrencilerin yetersiz olduğu tespit edilmiştir.

Cümle akıcılığı boyutuna ait son rubrikte dönüt verme ve düzeltme türlerinin grupları farklı şekilde etkilediği tespit edilmiştir. Dönüt verme ve düzeltme türlerinin uygulandığı cümle akıcılığı boyutunun alt kategorileri olan;

Cümlelerin oluşturulmasına özen gösterilmesini AGS1, AGS2, BGS2 kişileri;

Cümlelerin verilmek istenen fikri yansıtmasını AGS1, CGS1 kişileri;

Cümlelerin uzunluk ve yapı olarak çeşitlilik arz etmesini AGS1, AGS2, BGS2 kişileri;

Cümlelerin birbiriyle olan bağı iyi sağlanması, bağlaçların doğru kullanılması AGS2, AGS3 kişileri verdikleri doğru cevaplarla son rubrikte anlamlı farklılık oluşturmuşlardır. Bu durumda dönüt verme ve düzeltme türleri son rubrikte $A$ grubu lehine anlamlı bir artış gösterirken, B grubuna uygulanan dönüt verme türü $C$ grubuna göre anlamlı bir artış göstermiş̧ir. C grubunda sadece aldıkları puan dönütü uygulanmış ve bu dönüt neticesinde anlamlı bir fark oluşmamıştır. Bu sonuçla yazma eğitiminde cümle akıcılığı boyutunda dönüt verme ve düzeltme birlikte kullanılmalıdır denilebilir.

6+1 analitik yazma rubriğinin imla boyutuna ait bulgular Tablo 11'de verilmiştir. Tablo 11

6+1 Analitik Yazma Rubriğinin Imla Boyutu Analizi

\begin{tabular}{lll}
\hline İmla Boyutu & Ön Rubrik & \multicolumn{1}{c}{ Son Rubrik } \\
\hline Büyük harf kullanımının doğru uygulanmış & BGÖ2; CGÖ1 & AGS1, AGS2, AGS3; BGS1; CGS1 \\
$\begin{array}{l}\text { Kelimeler doğru şekilde yazılmış } \\
\text { Noktalama işaretlerini doğru şekilde }\end{array}$ & AGÖ1; BGÖ1; CGÖ1 & AGS1, AGS2; BGS1 \\
kullanılmış & AGÖ1; CGÖ1 & AGS1, AGS2, AGS3; BGS1 \\
$\begin{array}{l}\text { Dilbilgisi kurallarını (Ünsüz benzeşmesi, ünsüz } \\
\text { yumuşaması, ünlü düşmesi vb.) doğru }\end{array}$ & AGÖ1 & AGS1, AGS2; BGS1; CGS1 \\
kullanılmış & & AGS1, AGS2 \\
Paragraflar düzgün şekilde planlanmış & & \\
\hline
\end{tabular}

İmla boyutuna ilişkin Tablo 11 incelendiğinde, dönüt verme ve düzeltme türlerine ait uygulamaların grupları farklı düzeyde etkilediğini söylemek mümkündür. Bu bağlamda imla boyutunun alt kategorileri incelendiğinde son rubrik lehine nicel bir farklılık olduğu görülmektedir. Ön rubrikte dönüt verme ve düzeltme türlerinin imla boyutunun alt kategorileri olan;

Büyük harf kullanımının doğru uygulanmasında BGÖ2, CGÖ1 kişileri;

Kelimelerin doğru şekilde yazıımasındaAGÖ1, BGÖ1, CGÖ1 kişileri;

Noktalama işaretlerinin doğru şekilde kullanılmasında AGÖ1, CGÖ1 kişileri;

Paragrafların düzgün şekilde planlanmasına ait yazma becerisini ise hiçbir katılımcı gerçekleştirememiştir.

Dilbilgisi kurallarının doğru kullanılmasında AGÖ1 kişisi ön rubrikte yeterli bulunmuş diğer öğrencilerin yetersiz olduğu tespit edilmiştir.

Imla boyutuna ait son rubrikte dönüt verme ve düzeltme türlerinin grupları farklı şekilde etkilediği tespit edilmiştir. Dönüt verme ve düzeltme türlerinin uygulandığı imla boyutunun alt kategorileri olan;

Büyük harf kullanımının doğru uygulanmasını AGS1, AGS2, AGS3, BGS1, CGS1 kişileri;

Kelimelerin doğru şekilde yazıımasını AGS1, AGS2, BGS1 kişileri;

Noktalama işaretlerinin doğru şekilde kullanılmasını AGS1, AGS2, AGS3, BGS1 kişileri;

Dilbilgisi kurallarının doğru kullanılmasını AGS1, AGS2; BGS1, CGS1 kişileri;

Paragrafların düzgün şekilde planlanmasını AGS1, AGS2 kişileri son rubrikte verdikleri doğru cevaplarla puanlarını arttırmıştır. Bu veriler A grubuna uygulanan dönüt verme ve düzelteme türlerinin diğer gruplara göre daha olumlu fark oluşturduğunu göstermektedir. 
Bu sonuçla yazma eğitiminde imla boyutunda dönüt verme ve düzeltme birlikte kullanılmalıdır denilebilir. Tablo 12

6+1 analitik yazma rubriğinin sunum boyutuna ait bulgular Tablo 12' de verilmiştir.

$6+1$ Analitik Yazma Rubriğinin Sunum Boyutu Analizi

\begin{tabular}{lcc}
\hline Sunum Boyutu & Ön Rubrik & Son Rubrik \\
\hline $\begin{array}{l}\text { Harflerin yazımında kullanılan eğiklik } \\
\text { ve kelimeler arası boşluk uyumu }\end{array}$ & AGÖ2; CGÖ1 & AGS1, AGS2, AGS3; BGS1; CGS1 \\
$\begin{array}{l}\text { Sayfada bırakılan boşluklar okuyucunun } \\
\text { dikkatini dağıtmıyor }\end{array}$ & AGÖ1; BGÖ1; CGÖ1 & AGS1, AGS2, AGS3; BGS1; CGS1 \\
$\begin{array}{l}\text { Başlık, alt başlık ve numaralandırımalar } \\
\text { kullanışlı }\end{array}$ & AGÖ1; CGÖ1 & AGS1, AGS2, AGS3; BGS1
\end{tabular}

Sunum boyutuna ilişkin Tablo 12 incelendiğinde, dönüt verme ve düzeltme türlerine ait uygulamaların grupları farklı düzeyde etkilediğini söylemek mümkündür. Bu bağlamda sunum boyutunun alt kategorileri incelendiğinde son rubrik lehine nicel bir farklılık olduğu görülmektedir. Ön rubrikte dönüt verme ve düzeltme türlerinin sunum boyutunun alt kategorileri olan; kişileri;

Harflerin yazımında kullanılan eğiklik ve kelimeler arası boşluğa uyulmasını AGÖ2, CGÖ1

Sayfada bırakılan boşluklar okuyucunun dikkatini dağıtmamasını AGÖ1, BGÖ1, CGÖ1 kişileri;

Başlık, alt başlık ve numaralandırımaların kullanılması AGÖ1; CGÖ1 kişileri ön rubrikte yeterli düzeyde sağlamışlardır. Ancak diğer öğrencilerin yetersiz olduğu tespit edilmiştir.

Sunum boyutunda son rubrikte dönüt verme ve düzeltme türlerinin farklı şekilde uygulandığı gruplarda anlamlı farklılık olduğu görülmüştür. Dönüt verme ve düzeltme türlerinin uygulandığı sunum boyutunun alt kategorileri olan;

Harflerin yazımında kullanılan eğiklik ve kelimeler arası boşluğa uyulmasını AGS1, AGS2, AGS3, BGS1, CGS1 kişileri;

Sayfada bırakılan boşluklar okuyucunun dikkatini dağıtmamasını AGS1, AGS2, AGS3, BGS1, CGS1 kişileri;

Başık, alt başık ve numaralandırımaların kullanılmasını AGS1, AGS2, AGS3, BGS1 kişileri son rubrikte verdikleri doğru cevaplarla puanları artırmışlardır.

A grubundan 3 katılımcıdan düzeltme ve dönüt verme son rubrik lehine anlamlı bir artış gösterirken, $B$ grubuna uygulanan dönüt verme türü neticesinde $C$ grubuna göre anlamlı bir artı̧̧ göstermiştir. $C$ grubunda sadece aldıkları puan dönütü uygulanmış ve bu dönüt neticesinde diğer gruplarla anlamlı bir fark oluşmamıştır. Bu sonuçla yazma becerilerinin kazanımında sunum boyutunun öğretiminde dönüt verme ve düzeltme birlikte kullanılmalıdır denilebilir.

\section{SONUÇ, TARTIŞMA VE ÖNERILER}

Dönüt verme ve düzeltme iki yönü olan bir öğretim yöntemidir. Bu iki taraftan öğretici, öğrenenin davranışlarını değerlendirmeli, öğrenen ise öğreticinin dönütüne göre gerekli düzeltmeleri gerçekleştirmelidir. Dökmen'in (1982, s. 72) ifade ettiği gibi dönüt ve düzeltme, eğitim-öğretimde kullanılması gereken önemli bir unsurdur. Ancak, hangi tür dönüt verme ve düzeltmenin, hangi şartlarda, ne ölçüde yararlı olduğu yeterince netliğe kavuşmamıştır. Bu bağlamda bu araştırma bu tür soruların açığa çıkması açısından önemlidir. Çünkü bu araştırmada, öğretim sisteminde en çok tercih edilen üç türlü dönüt verme türü sınanmaya çalışılmıştır.

Eğitim sisteminin her aşamasında dönüt verme ve düzeltmenin uygulanması gerekmektedir. Dört dil becerisinden biri olan yazma becerisi diğer becerileri de içerisinde barındıran bir üst 
beceridir. Öğrencilerin en çok zorlandıkları dil becerisi yazma becerisidir. Yazı yazmak zor, belli birikim ve bilgi isteyen (Yalçın, 2006) yönlendirilmesi gereken bir uğraştır.

Araştırmada öğrencilerin yazma becerisine yönelik ortaya koydukları ürünler yedi boyut açısından değerlendirilmiştir. Bu yedi boyut açısından oluşturulan üç gruba ait nicel ve nitel bulgulara bakıldığında A grubuna uygulanan dönüt verme ve düzeltmenin birlikte kullanılmasının diğer gruplara uygulanan dönüt türlerine oranla daha olumlu sonuçlar verdiği söylenebilir. Bu yönüyle yapılan bu araştırma dönüt verme ve düzeltme üzerine yapılan (Black ve ark., 2002; Butler, 1987; Crooks, 1998; Elawar ve Corno, 1985; Rowntree, 1987) araştırmalar ile benzerlik göstermektedir. Elawar ve Corna (1985), ortaokul öğrencilerinin yazma becerisinde dönütün etkisini inceledikleri araştırmada, dönüt uygulanan öğrencilerin olumlu gelişme gösterdikleri sonucuna varmıştır. Yapılan bu araştırma alandaki diğer araştırmalarla sonuçları açısından benzerlik gösterse de yazma becerisinin boyutları açısından dönüt verme türlerinin etkisinin incelenmesi yönüyle farklılık göstermektedir. Yazma becerisinin boyutları dönüt verme türlerinden, süreç ve diğer becerilerle olan ilişkisi açısından farklı şekilde sonuç vermiştir. Yazma becerisinin organizasyon boyutunun gelişmesi için dönüt verme ve düzeltmenin mutlaka birlikte uygulanması gerektiğini; üslup boyutunda dönüt türleri arasında anlamlı bir fark olmadığı bu nedenle bu boyuta ait çalışmaların daha uzun süreçli ve diğer dil becerilerini de kullanarak gelişebileceğini söyleyebiliriz. Yazma becerisinin imla boyutunda ise diğer boyutlara kıyasla dönüt verme ve düzeltme daha olumlu sonuç vermiştir. Bu sonuçla dönüt verme ve düzeltme türleri imla boyutunda daha fazla yararlıdır diyebiliriz. Ancak öğretmenlerin de daha çok imla boyutunda dönüt verdikleri buna karşılık dil ve anlatım boyutlarını içeren kııımlarda gereği kadar dönüt vermedikleri bilinmektedir. Ronayne (2002), dönüt türlerinin yazma becerisine etkisini belirlediği çalışmada dönütleri "motive edici, organizasyona yönelik, yapıcı ve düşünmeye yönelik" biçiminde sınıflandırmış ve değerlendirmiştir. Ronaye (2002) çalışmasında öğretmenlerin yazma becerisinin organizasyon boyutuna ait dönütler verdiği, ancak dil ve anlatım yönünden dönütlere yer vermedikleri sonucuna varmıştır. Bu yönüyle Ronayne' nin (2002) yaptığı araştırma bu araştırmayı desteklemektedir.

Dönüt verme ve düzeltmenin öğrenme sürecinde etkili bir öğe olduğu (Kara, 1994), öğretimin niteliğinin sağlanmasında en önemli etken olduğu (Bloom, 1995) belirtilmektedir. Walberg (1984), yaptığı araştırmada öğrenci başarısında etkili olan 26 madde belirlemiş bu maddeler arasında dönüt vermenin üçüncü sırada yer aldığı tespitinde bulunmuştur (Walberg, 1984'ten aktaran Adrienne, 1997).

Bu araştırmadan elde edilen veriler sonucunda yazma becerisinin gelişmesinde dönüt verme ve düzeltmenin birlikte kullanılmasının faydalı olacağı sonucuna varılmıştır. Higgins, Hartley ve Skelton (2002), yaptıkları araştırmada öğrenciler yazılı dönütlerin bireysel hatalarını görmelerinde ve yazma becerilerini geliştirmelerinde faydalı olduğunu ifade etmişlerdir. Öğretmenlerin bir eğitim öğretim yılı içerisinde yaptıkları yazılı yoklamalarda bile uygulayabilecekleri altı boyutlu dönüt verme ve düzeltmenin öğrencilerin yazma becerisine olumlu katkısı olabileceği bu araştırma ile de ortaya konmuştur. Bu bağlamda program geliştiriciler, program uygulayıcılar dönüt verme ve düzeltme üzerinde çalışmalı ve gerekli önlemeleri almalıdırlar.

\section{KAYNAKLAR}

Adrienne, R. (1997). Feedback: Enhancing the performance of adult learners with learning disabilities. National Adult Literacy and Learning Disabilities Center, Washington, DC.

Akbayır, S. (2010). Yazılı anlatım nasıl yazabilirim? Ankara: Pegem Akademi Yayıncılık.

Aktaş, Ş. ve Gündüz, O. (2007). Yazılı ve sözlü anlatım. Ankara: Akçağ Yayınları. 
Akyıldız, H. (1996). Eğitim ortamındaki iletişim kaynak ve süreçlerinin uzaktan eğitim açısından değerlendirilmesi. I. Uluslararası Uzaktan Eğitim Sempozyumu, Ankara.

Alavi, S. M. ve Kaivanpanah, S. (2007). Dönüt beklentisi ve EFL öğrencilerinin İngilizce başarısı. Kuram ve Uygulamada Eğitim Bilimleri, 3(2), 181-196.

Bacanlı, H. (1999). Gelişim ve öğrenme. Ankara: Nobel Yayınları.

Baker, D. F. \& Buckley, M. R. (1996). A historical perspective of the impact of feedback on behavior. Journal of Management History, 2(4), 21-33.

Bekiroğlu, F. O. (2008). Performansa dayalı ölçümler: Teori ve uygulama. Türk Fen Eğitim Dergisi, 5(1), 113-131.

Black, P., Harrison, C., Lee, C., Marshall, B. \& Wiliam, D. (2002). Working inside the black box: Assessment for leaning in the classroom. London, UK: King's College, London School of Education.

Bloom, B. S. (1995). Insan nitelikleri ve okulda öğrenme (Çev. D. A. Özçelik). İstanbul: Milli Eğitim Basımevi.

Bilen, M. (1996). Plandan uygulamaya öğretim. Ankara: Aydan Web Tesisleri.

Bilgin, N. (2006). Sosyal bilimlerde içerik analizi, teknikler ve örnek çalışmalar. Ankara: Siyasal.

Butler, R. (1987). Task-involving and ego-involving properties of evaluation: Effects of different feedback conditions on motivational perceptions, interest and performance. Journal of Educational Psychology, 79(4), 474-482.

Büyüköztürk, Ş., Kılıç, Ç. E., Akgün, Ö. E., Karedeniz, Ş. ve Demirel, F. (2011). Bilimsel araştırma yöntemleri. Ankara: Pegem Akademi Yayınları.

Coşkun, E. (2005). ilköğretim öğrencilerinin öyküleyici anlatımlarında bağdaşıklık, tutarlılık ve metin elementleri. (Yayımlanmamış Doktora Tezi). Gazi Üniversitesi, Ankara.

Creswell, J. W. (2009). Research design: qualitative, quantitative and mixed methods approaches (3. Baskı). London: Sage.

Crooks, J. (1998). The impact of classroom evaluation practices on students. Review of Educational Research, 58(4), 438-481.

Demirel, Ö. (1999a). Plandan değerlendirmeye öğrenme sanatı. Ankara: Pegem Akademi Yayınları.

Dökmen, Ü. (1982). Geri bildirimlerin öğrenmeye etkisi. Ankara Üniversitesi Eğitim Bilimleri Dergisi, 71-80.

Elawar, M. C. \& Corno, L. (1985). A factorial experiment in teachers' written feedback on student homework: Changing student behavior a little rather than a lot. Journal of Educational Psychology, 77(2), 162-173.

Güneş, F. (2007). Türkçe öğretimi ve zihinsel yapılandırma. Ankara: Nobel Yayın Dağıtımı.

Higgins, R., Hartley, P. \& Skelton, A. (2002). The conscientious consumer: reconsidering the role of assessment feedback in student learning. Studies in Higher Education, 27(1), 53-64.

Kara, Z. (1994). İ̧̧bilirliğine dayalı paylaşmalı dönütün başarı ve hatırda tutma üzerindeki etkileri. 1. Eğitim Bilimleri Sempozyumunda Sunulan Bildiri, Bildiri Metinleri II, Çukurova Üniversitesi, Balcalı Eğitim Fakültesi Yayınları, 494-507.

Karatay, H. (2013). Süreç temelli yazma modelleri, M. Özbay (Ed.), Yazma eğitimi içinde (s. 21-40). Ankara: Pegem Akademi Yayınları. 
Karasar, N. (2013). Bilimsel araştırma yöntemi. Ankara: Nobel Yayın Dağıtımı.

Kavcar, C., Oğuzkan, F. ve Aksoy, Ö. (2004). Türkçe öğretimi. Ankara: Engin Yayıncılık.

Kıncal, R. Y. (2010). Bilimsel araştırma yöntemleri. Ankara: Nobel Yayın Dağıımı.

Köksal, K. (2001). Okuma yazmanın öğretimi. Ankara: Pegem Akademi Yayınları.

Kuckartz, U. (2014). Qualitative text analyses: a guide to methods, practice \& using software. London: Sage.

Kuzu, A. (2013). Veri toplama yöntem araçları. A. A. Kurt (Ed.). Bilimsel araştırma yöntemleri içinde (s. 95-118). Eskişehir: Anadolu Üniversitesi Yayınları.

MEB (2006). ilköğretim Türkçe dersi öğretim programı ve kılavuzu (6-8. Sınıflar). Ankara: Milli Eğitim Basımevi.

Özbay, M. (2006). Türkçe özel öğretim yöntemleri II. Ankara: Öncü Kitap.

Özçelik, D. A. (1992). Eğitim programları ve öğretimi. Ankara: ÖSYM Yayınları.

Özkara, Y. (2007). 6+1 Analitik yazma ve değerlendirme modelinin 5. sınıf öğrencilerinin hikâye edici metin yazma becerilerini geliştirmeye etkisi (Yayımlanmamış Doktora Tezi). Gazi Üniversitesi, Ankara.

Peker, R. (1992). Geri bildirimin üniversite öğrencilerinin ölçme ve değerlendirme dersindeki başarısına etkisi. Uludağ Üniversitesi Eğitim Fakültesi Dergisi, 7(1), 31-39.

Ronayne, M. (2002). Marking and feedback. SET: Research Information for Teachers, 2, 8-11.

Rowntree, D. (1987). Assessing students: How shall we know them? London: Kogan Page.

Sadler, D. R. (1989). Formative assessment and the design of instructional systems. Instructional Science, 18, 119-144.

Schimmel, B. J. (1988). Providing meaningful feedback in courseware. In D. Jonassen (Ed.), Instructional designs for microcomputer courseware (s. 183-195). Hillsdale, NJ: Lawrence Erlbaum Associates.

Sever, S. (2011). Türkçe öğretimi ve tam öğrenme. Ankara: Anı Yayıncılık.

Sönmez, V. (1994). Program geliştirmede öğretmen el kitabı. Ankara: Pegem Akademi Yayınları.

Tata, J. (2002). The influence of managerial accounts on employees reactions to negative feedback. Group \& Organization Management, 27(4), 480-503.

Temizkan, M. (2003). Türkçe öğretmenlerinin yazılı anlatım etkinliği çerçevesinde yaptıkları uygulamaların değerlendirilmesi. Milli Eğitim, 174, 135-154.

Ünalan, Ş. (2001). Türkçe öğretimi. Ankara: Nobel Yayın Dağııımı.

Yalçın, A. (2006). Türkçe öğretim yöntemleri yeni yaklaşımlar. Ankara: Akçağ Yayınları.

Walberg, H. (1984). Improving the productivity of America's scholls. Educational Leadership, 4(8), 1927. 


\section{SUMMARY}

It needs to be made correction and give feedback in relation to the level of intended learning to take place the high quality and learning whether student learn or not. According to Bacanlı(1999, s. $110)$, students should learn if there is a sufficient knowledge before motivation disappears. In this context giving feedback and correction are the major factors in the increasing of the quality of teaching for education. English "feedback" giving feedback that is expressed in Turkish Özçelik (1992) stated as "feedback, giving feedback, and information of results", used as a correction and giving feedback in this study. Using types of giving feedback and correction after writing provides the realization of the desired changes in behaviour. Giving feedback provides information about the truth or fault of human behaviour ( Peker, 1992, s. 35), whereas correction is a process that shows the methods how these improper behaviours are corrected. Giving feedback and correction often used together in the education process. (Demirel, 1999a, s. 135) When student and teacher give mutual feedback in the classroom due to the stimulating, feinforcing and guiding features of giving feedback are affected the quality of education in a positive way. (Dökmen, 1982; Sönmez, 1994; Tata, 2002).

Sadler ( 1989), expressed these points giving feedback and correction will be able to be useful in writing skills.

a) The students which knowledge and skills should have

b) Make comparison of works according to students' knowledge and skills

c) Recommend to the students what they can do

Writing skills can be acquired by the application of knowledge like as other languages. Writing skill is a language skill that keeps back thinking skills more than other skills such as using guided expression, classification, assessment, understanding, summarising and mental skills.(Güneş, 2007, s. 159) In this context, students do writing ability in a correct and nice way can be so difficult. At this stage, teachers are required to guide the use and gain the writing skills of the student. It is thought that teachers' feedback and correction improved the writing skills in a positive way. It is tested at what level the effect of giving feedback and corection types on writing skills. For this purpose it has tried to answer the following questions.

1) Which level of the effect on sixth grade students' writing skills to giving feedback and types of correction?

2) How is the situation according to giving feedback and correction types on sixth grade students' 6+1 Analytical Writing Assessment Rubrıg?

This study was designed with mixed method in descriptive figure. The study group consists of 115 sixth grade students in the city of Kahramanmaraş in the 2015-2016 academic year.

Products, intended for the writing skills, were evaluated for seven dimensions. Created by three groups in terms of seven dimensional quantitative and qualitative findings are occured and using together feedback and correction applied to the group A may give positive results compared to the other groups' feedback.

It is concluded that the data obtained from this research, using together correction and giving feedback will be helpful for the development of writing skills. Higgins, Hartley and Skelton (2002) expressed that written feedback is helpful for improving students' writing skills and they notice their individual errors. Even in teachers' written examination in an academic year they apply six dimensional giving feedback and correction affect writing skills in apositive contribution, is demonstrated with this research. In this context program developers, program implementers should work on giving feedback and correction and make necessary prevention. 